\title{
STRATEGIES IN AUTONOMOUS LEARNING OF PROFESSIONALLY ORIENTED ENGLISH COMMUNICATION
}

\author{
Natalia Dmitrenko ${ }^{1}$, Anastasiia Petrova $^{1}$, Olena Podzygun ${ }^{1}$, Sofiya Nikolaeva ${ }^{2}$ \\ ${ }^{1}$ Vinnytsia Mykhailo Kotsiubynskyi State Pedagogical University, Vinnytsia, Ukraine \\ ${ }^{2}$ Kyiv National Linguistic University, Kyiv, Ukraine
}

\begin{abstract}
The article presents learning strategies that affect the process of students' autonomous learning of professionally oriented English communication. The article provides various definitions and main characteristics of learning strategies used in the process of mastering English as a foreign language, and a number of factors that influence the students' choice of learning strategies as well. The learning strategy of autonomous learning is defined as a course of a goal-seeking and controlled behavior, which is organized in a certain way and is chosen by students to perform the tasks that they set for themselves. The study describes an explicit model of mastering strategies based on instructions, Oxford's Strategy Training Model (STL), which was introduced in autonomous learning of professionally oriented English communication. The main steps for the model implementation are presented and conditions, which are to be followed in its application, are identified. Experimental training with the use of the mentioned model of mastering strategies based on instructions was conducted among first-year students of the Pedagogical University, who are autonomously learning English as a foreign language. The analysis of the research results confirmed the effectiveness of the chosen model of mastering strategies based on instructions in the process of autonomous learning of professionally oriented English communication. The use of this model makes the learning process more efficient as it increases the student's motivation and self-confidence, forms autonomy and independence, shows the interaction of foreign language learning strategies with other disciplines, makes the learning process open and clear, forms responsibility, and teaches introspection and task modification.
\end{abstract}

Key words: learning strategies, autonomous learning, professionally oriented English communication, intending educators

\section{INTRODUCTION}

Active use of foreign language learning strategies helps students to control their own learning, develop language and speech skills, increase confidence and motivation to learn a language. Applying learning strategies increases autonomy and promotes students take responsibility for their learning. The more strategies students use the more confident, motivated and independent they feel. The priority task of the teacher is the selection of

Submitted August 16 $6^{\text {th }}, 2020$, accepted for publication March $19^{\text {th }}, 2021$

Corresponding author: Natalia Dmitrenko. Vinnytsia Mykhailo Kotsiubynskyi State Pedagogical University, Vinnytsia, Ukraine | E-mail: nataliadmitrenko0302@gmail.com 
appropriate teaching methods and strategies for students and the formation of their ability to use these strategies properly to increase the level of their autonomy in learning.

The research aim was to determine the level of strategies acquisition in autonomous learning of professionally oriented English communication, as well as analysis of the data and determine the impact of strategies on learning results.

In the study, autonomous professionally oriented English communication is defined as a free, self-selected and managed, internally motivated learning activity to master professionally oriented English communication, which involves students to perform a set of action sequences: defining aims and objectives of educational activities, subordination of interests to the aim achievement, self-management in determining the educational activities and time for their implementation, and self-control of educational activities as well.

\section{LITERATURE REVIEW}

Learning strategy is also interpreted as purposeful thinking and behavior in order to remember and understand new information in the learning process (Oxford et al., 1988). Oxford (1990, p. 6) explained that "strategies are especially important for language learning, because they are a tool to stimulate independent activity, which is important for the development of communicative competence". Oxford's definition has gained a positive resonance in the professional environment, and has become the most cited in the scientific and methodological literature. According to the authoritative researcher, foreign language learning strategies are "specific actions, taken by the learner to make learning easier, faster, more enjoyable, more self-directed, more effective, and more transferrable to new situations"(Oxford, 1990, p. 8). It is a reflection of what the students intend to do and of the specific actions, they can take. The use of strategy is useful and effective if: a) the strategy is well combined with the purpose and task of mastering a foreign language, b) the strategy corresponds to the individual learning style of the student, and c) the student effectively uses the strategy and combines it with other relevant strategies (Oxford, 1990, p. 8).

Foreign language learning strategies have been described by Wenden and Rubin (1987) as "any set of operations, steps, plans, procedures used by a student to facilitate the acquisition, storage, retrieval, and use of information". Richards et al. (1992, p. 209) have argued that learning strategy is a goal-seeking thinking and behavior of the students during learning that help them find, understand, and remember new information. This definition related to the definitive characterization proposed by O'Malley and Chamot (1990, p. 1), who have understood learning strategies as conscious thoughts and actions that learners take in order to understand, learn or store new information. Ellis (1994) has defined language learning strategies as the processes by which students accumulate new rules and automate existing knowledge through the processing of perceived information and simplification of it through experience. Thus, learning strategies are defined by experts as special ways of processing information that improve the understanding, study or storage of information. In addition, Cohen (1990, p. 4) have argued that foreign language learning strategies are a process of students' conscious choice of actions they take to make learning more effective or improve the use of a foreign language by means of storage, reproduction and application of the information about this language.

Thus, Faerch and Casper (1989) have emphasized that the learning strategy itself is an attempt to develop linguistic and sociolinguistic competence by means of the foreign 
language, which is being studied. In the Common European Framework of Reference for Languages (CEFR) (Council of Europe, 2018), learning strategies refer to the intellectual tools that language learners use to mobilize and balance their resources, to enhance skills in order to meet their communication needs in a specific situation and to complete the task successfully in the most comprehensible and economical way depending on a specific purpose. The application of strategies can be considered as the implementation of cognitive principles of planning, accomplishment, control and correction in various types of communicative activities: perception, interaction, production and mediation.

Learning strategies are defined as self-regulatory tools aimed at achieving and developing communication skills. Unlike teaching methods, learning strategies are of a rather complex and complicated character. It is a great number of actions, which are taken to achieve a goal. The strategy is a gradual sampling of successive temporary goals, which are dedicated to a common target goal, and the means of its proper application. According to Ellis (1994), Oxford and Cohen (1992), learning is a short-term application of specific behaviors or devices, while learning strategies are long-term processes, and students use different strategies at different stages of the learning process. Students resort to different learning strategies when they encounter different problems in the process of learning a foreign language, so learning strategies are problem-oriented (Dmitrenko et al., 2020).

Learning strategies used in the language learning process are classified by many language learning professionals, among them there are Bialystok (1981), Bimmel and Rampillon (1999), Ellis (1994), Oxford (1990), O’Malley et al. (1985), Stern (1992), Willing (1988), and others. The classification of language learning strategies has helped to link strategies to different phases of cognition in language learning. At the same time, the researchers developed their own taxonomy of strategies as part of their research, using different data collection methods. It should be noted that most of these attempts to classify language learning strategies are relatively the same and do not contain noticeable differences (Zare, 2012, p. 164). Analysis of scientific literature suggests that scientists' understanding of classifications of foreign language learning strategies is based on different levels: more general and specific, in accordance with close and promising learning goals (Shi, 2017). Thus, the main strategies of autonomous professionally oriented English communication are: 1) strategies for overcoming speech difficulties in foreign language proficiency (direct strategies): memorization, cognitive, and compensatory strategies; 2) strategies for organizing autonomous learning of professionally oriented communication in a foreign language (indirect strategies): metacognitive, affective and social strategies.

The analysis of scientific literature on the researched problem has shown that various factors influence students' choice of foreign language learning strategies. For instance, Ellis (1994) has distinguished individual, social and situational factors that influence the students' choice of learning strategies. Chamot and Kupper (1989), Oxford and Ehrman (1995), Oxford et al. (1988) have identified factors that influence the choice of foreign language learning strategies: age, gender, learning style, cultural background, type of tasks, motivation, learning context, language skills, attitude and perception of the educator.

Many scientific studies (Anderson, 2005; Bruen, 2001; Green \& Oxford, 1995; Griffiths, 2003; Lee, 2003; O’Malley \& Chamot, 1990; Rahimi et al., 2008) have dealt with the interaction between learning strategies and students' knowledge. Their results have shown that those students who regularly use different learning strategies make progress in language acquisition. It has been found out that the choice of strategies is also influenced by individual learning style (Oxford \& Cohen, 1992). It is the individual learning styles of students that play 
a crucial role in choosing language learning strategies. It is evident that a confluence of individual learning styles and language learning strategies is necessary. Due to this fusion, students will succeed in their foreign language communication, feel confident and calm (Oxford, 2003).

The analysis of scientific research has shown that among the above mentioned ways of mastering strategies, the most effective one is the last way - to integrate learning with the study of language strategy instructions into a foreign language lesson. Chamot and O'Malley (1987), Oxford and Leaver (1996) have indicated that compared to isolated (separate from practice) lectures and workshops, integrated learning strategies are much more effective. They can be incorporated into curricula to optimize learning, as it involves the use of authentic speech learning tasks and their long-term implementation (Lai, 2013).

Grenfell and Harris (1999), Oxford (1990) have noted that instructions for the application of learning strategies should be provided explicitly, integrating them into the practical course of learning a foreign language.

Unlike the implicit presentation of strategies, which does not provide students with special guidance on the purpose of learning (why to learn), explicit instructions cultivate a conscious attitude to the application of strategies, present the strategy, model its practical use, help assess its effectiveness. Thus, informing students about how, when and why strategies are used, enabling them to apply strategies in different learning tasks and transfer the implementation of strategies in new contexts and tasks, which is extremely important in autonomous learning of professionally oriented English communication for intending educators (Dmitrenko et al., 2020).

The scientific literature have presented various explicit models of mastering strategies based on instructions in the process of learning a foreign language, among which the most notable are: Pearson and Dole (1987), Oxford (1990), Chamot (2005), Cohen (2000), Grenfell and Harris (1999), and others. Explicit instructional strategies for learning English were found to be more widely and effectively used in the learning process than implicit models.

For the research, Oxford's Strategy Training Model (STL) has been chosen (Oxford, 1990), which belongs to explicit instructional strategies for learning English. The Strategy Training Model has a step-by-step application and is flexible in terms of procedure. It means that each step can be changed or done anew according to the tasks with different requirements and intentions. Implementation of the model consists of the following steps: 1) The student is asked to be deep in an authentic language task and do it without teacher's instructions and guidance on the learning strategy. 2) The teacher helps students evaluate the strategy that has been used. 3) The teacher suggests and demonstrates useful learning strategies, emphasizes the necessity of self-management and mentions the expected results. He / she also makes sure that students are aware of the rationality of the strategy, which is being used. 4) The teacher gives students some time for the practical application of new learning strategies doing language or speech tasks and shows how these strategies can be applied to other tasks. 5) The teacher provides the practice of using techniques with new tasks and allows students to make a choice of what learning strategies they will use to do language learning tasks. 6) The teacher helps students understand how to evaluate the success of their learning strategy and measure their progress as responsible and independent students. 


\section{Methodology}

Implementing the Strategy Training Model, the repertoire of strategies for a foreign language acquisition is formed by each student individually and can remain unchanged or expand due to new strategies. While giving instructs to students on the learning strategies, it is necessary to follow the basic rules:

1) students should be explained the importance of learning strategies while learning and using a foreign language;

2) it is necessary to show the benefits of using learning strategies for improving learning efficiency;

3) each strategy should be named (it does not necessarily have to coincide with the official name used in the scientific and methodological literature, for example, 'selectivity of attention' can be reformulated as 'pay attention to the main'). It increases students' awareness of cognitive processes, helps to remind of the necessary strategy when the teacher assists;

4) students should be given the opportunity to practise appropriate learning strategies in doing various tasks;

5) it is important to teach students to evaluate the success of a particular learning strategy for the desired result. This process requires discussion and analysis of the strategies, which are used, at the same time, it is important to encourage students to transfer learned strategies to new tasks.

\subsection{Instrument and Procedures}

The main procedure ways for students to master learning strategies in the autonomous learning of professionally oriented English communication were determined:

1. Detecting the level of learning strategies acquisition using the questionnaire "Strategy Inventory for Language Learning" (Version 7.0) (Oxford, 1990).

2. Acquaintance with the repertoire of strategies based on the list of strategies "Language Strategy Use Survey" (Cohen, 2006) proposed by the teacher.

Due to this list students determine what learning strategies and to what extent they will apply in different types of speech activity.

3. Implementation of the Strategy Training Model:

- demonstration of learning strategies application by the teacher with comments and taking into account the individual learning style;

- implementation of an explicit model of learning strategies on the basis of instructions and use of learning strategies by the student with common comments of the teacher and the student;

- independent implementation of learning strategies, further expansion of the repertoire of learning strategies;

- self-assessment and reflection by the student of the process and result, developing strategic prospects.

4. After completing the training with the use of the explicit Oxford's model to master learning strategies, the students were asked to re-take the questionnaire "Strategy Inventory for Language Learning", to determine the changes in the level of learning strategies acquisition in the process of learning a foreign language.

Simultaneously, the control test to determine the level of academic achievement was conducted at the beginning and end of experimental training. 


\subsection{Participants}

The research was conducted with 58 first-year students (35 females and 23 males) of Vinnytsia Mykhailo Kotsiubynskyi State Pedagogical University, majoring in Mathematics, Computer science, Philology, Psychology, who study English for special purposes as a foreign language. The training was introduced during two terms in the 2018/2019 academic year and was carried out without special selection of students, in standard conditions of the usual educational process in subgroups of 14-15 students (4 subgroups). An introductory interview was held with the students of the experimental groups, during which the purpose and objectives of the experimental training were announced and it was explained that the results of the questionnaire would not affect the assessment of students' proficiency.

In the process of the experimental training, all students of the experimental groups worked with the same educational materials and control tests for listening, speaking, reading and writing. All students were assessed on the same criteria that meet the level of B1 language according to CEFR and the tests were conducted at the beginning and the end of the experimental training.

\subsection{Data Analysis}

The results of the adapted version 7.0 of Oxford's questionnaire "Strategy Inventory for Language Learning" for foreigners who learn English (Oxford, 1990) were analysed in order to determine the levels of implementation of learning strategies in the process of language mastering.

Oxford's questionnaire "Strategy Inventory for Language Learning" contains six categories of strategies, which include fifty questions on a five-point Likert scale ( 5 - always use, 4 - usually use, 3 - sometimes use, 2 - usually do not use, 1 - never use), among which: strategies of effective memorization (category A, questions 1-9), strategies of using all mental processes (category B, questions 10-23), compensatory strategies (category C, 24-29 questions), learning organization and assessment strategies (category $\mathrm{D}, 30-38$ questions), emotion management strategies (category E, 39-44 questions), learning strategies of collaboration with others (category F, 45-50 questions). The answers to each question (from 1 to 5) in each category are added and divided by the total number of statements of the corresponding category to obtain mean values. According to the Oxford's questionnaire, $a$ high level of strategies acquisition in language learning covers the mean values of 5.0-4.5 (always use) and 4.4-3.5 (usually use); a moderate level is in the range of 3.4-2.5 (sometimes use) and 2.4-1.5 (usually do not use); a low level has a mean value of 1.4-1.0 (never use).

In order to ascertain whether the difference in results obtained before and after the experimental training is significant statistically, $t$-value, $p$-value, and Pearson's correlation coefficient were applied. 


\section{RESULTS}

The results of the questionnaire on the use of strategies in language learning at the beginning of the experimental training are shown in table 1 .

Table 1 Mean values of the level of strategies acquisition before experimental learning

\begin{tabular}{|c|l|c|c|c|}
\hline № & Category & N & M & $\begin{array}{c}\text { Level of strategies acquisition in } \\
\text { autonomous learning of professionally } \\
\text { oriented English communication }\end{array}$ \\
\hline A & Strategies for effective memorization & 58 & 2.94 & moderate \\
\hline B & Strategies for using all mental processes & 58 & 2.92 & moderate \\
\hline C & Compensatory strategies & 58 & 3.14 & moderate \\
\hline D & Learning organization and assessment strategies & 58 & 3.05 & moderate \\
\hline E & Emotion management strategies & 58 & 2.66 & moderate \\
\hline F & Learning strategies in collaboration with others & 58 & 3.16 & moderate \\
\hline & Average value for all categories & 58 & 2.97 & moderate \\
\hline
\end{tabular}

Analyzing the individual indicators of 58 students, it should be noted that 11 first-year students have indicators of high average values over 3.5, but only four of them have the values close to $4(4.0 ; 4.1 ; 4.1 ; 4.4)$. Thus, these students usually use language learning strategies, but not always. At the same time, 12 students hardly use language learning strategies, as the average values of their answers are lower than 2.4.

After the experimental study, a repeated survey of students was conducted, the results of which are presented in table 2 .

Table 2 Mean values of the level of strategies acquisition after experimental learning

\begin{tabular}{|c|l|c|c|c|}
\hline № & \multicolumn{1}{|c|}{ Category } & N & M & $\begin{array}{c}\text { Level of strategies acquisition in } \\
\text { atonomous learning of professionally } \\
\text { oriented English communication }\end{array}$ \\
\hline A & Strategies for effective memorization & 58 & 3.84 & high \\
\hline B & Strategies for using all mental processes & 58 & 3.89 & high \\
\hline C & Compensatory strategies & 58 & 4.32 & high \\
\hline D & Learning organization and assessment strategies & 58 & 4.01 & high \\
\hline E & Emotion management strategies & 58 & 3.61 & high \\
\hline F & Learning strategies in collaboration with others & 58 & 4.54 & high \\
\hline & Average value for all categories & 58 & 4.04 & high \\
\hline
\end{tabular}

Table 2 shows that at the end of the experimental training based on the explicit STL model, the level of strategies acquisition in autonomous learning of professionally oriented English communication for intending educators in all categories of the questionnaire reached a high level. The increase in mean values by category $(\mathrm{A}, \mathrm{B}, \mathrm{C}, \mathrm{D}, \mathrm{E}, \mathrm{F})$ is presented in table 3 . 
Table 3 Comparison of mean values of strategies acquisition in learning English by intending educators at the beginning and after experimental training

\begin{tabular}{|c|l|c|c|c|c|}
\hline № & Category & $\mathrm{N}$ & $\begin{array}{c}\mathrm{M} \\
\text { (before) }\end{array}$ & $\begin{array}{c}\mathrm{M} \\
\text { (after) }\end{array}$ & Increase in Value \\
\hline A & Strategies for effective memorization & 58 & 2.94 & 3.84 & +0.9 \\
\hline $\mathrm{B}$ & Strategies for using all mental processes & 58 & 2.92 & 3.89 & +0.97 \\
\hline C & Compensatory strategies & 58 & 3.14 & 4.32 & +1.18 \\
\hline $\mathrm{D}$ & Learning organization and assessment strategies & 58 & 3.05 & 4.01 & +0.96 \\
\hline E & Emotion management strategies & 58 & 2.66 & 3.61 & +0.95 \\
\hline F & Learning strategies in collaboration with others & 58 & 3.16 & 4.54 & +1.38 \\
\hline & Average value for all categories & 58 & 2.97 & 4.04 & +1.07 \\
\hline
\end{tabular}

Thus, the increase in the level strategies acquisition in autonomous learning of professionally oriented English communication for intending educators occurred in all categories, on average by +1.07 . The highest increase is observed in the category "Learning strategies in collaboration with others" $(+1.38)$.

At the same time, according to the results of the control test to determine the level of academic achievement, which was conducted at the beginning and end of experimental training of using learning strategies, the percentage of students with low English communicative proficiency decreased in all communication activities, namely: listening $31 \%$, monologue $36 \%$, dialogue $33 \%$, reading $26 \%$, and writing $41 \%$.

In order to ascertain whether the difference in results obtained before and after the experimental training is significant statistically and how variables (scores on the English test and level of strategies acquisition in autonomous learning of professionally oriented English communication for intending educators) are correlated, we applied Pearson's correlation coefficient: $r=0.9876$. The positive correlation shows a strong relationship between the two variables. The $t$-value is $-6,678$ and the $p$-value is 0.000028 that signifies a significant correlation between the variables. The result is significant at $p<.05$. The results suggest that strategies acquisition in autonomous learning of professionally oriented English communication for intending educators could be very helpful in the development of English communicative proficiency and academic achievements.

\section{DISCUSSION}

As can be seen from the results of the questionnaire, the strategies acquisition in learning English by intending educators at the beginning of the experimental training was developed at a moderate level. The ability to use emotion management strategies was the least developed. It is worth noting that only four students approached the mean value of 4 in this category, which indicates that the level of skills in this category is approaching the lower limit. Thus, the students do not know how or rarely use strategies for complacency, encouragement, introspection of their own behavior, do not seek advice from a teacher or another person about their own emotional state.

At the beginning of the experimental training, the highest mean values were recorded in the category of using strategies in cooperation with others. Among the answers to the statements of this category, the following ones are highlighted: in case something is unclear, try to ask the interlocutor to repeat what was said (slower); speech practice with 
other students; trying to put questions in English; desire to learn about the cultures of native speakers. At the same time, high scores were given to the request for help and the desire to be corrected by the teacher if there were mistakes. That is, the students believe that if a problem arises, it is better for them to ask the teacher for help than to look for ways to solve it on their own, and they prefer the teacher's control or mutual control, rather than self-control and self-assessment.

The analysis of the questionnaire results indicates the feasibility of conducting the experimental training according to the explicit model of Oxford (STL) on the basis of instructions, in order to increase the level of language learning strategies acquisition to develop professionally oriented English communicative competence.

The results have shown that the level of mastery of strategies improved in all six groups of strategies presented in the survey. After the experimental training, students began to memorize better, use all their mental processes more effectively, developed the ability to compensate missing knowledge, organize and evaluate their learning more effectively, manage emotions and learn with others.

The best results were demonstrated in the application of strategies in cooperation / learning with other students. The results of the questionnaire show that students have learned to ask questions if they do not understand something, or to ask for help; ask to correct their mistake; practice English with other students and try to put questions in English. Students have become more interested in culture of the country whose language they are studying.

At the same time, the results of the control test to determine the level of language proficiency also have shown an increase in the level of language proficiency. Students who have shown the best results in the use of strategies, have shown the best results in the test of language competence as well.

The research has proved that successful students take a balanced approach to choosing strategies, depending on specific tasks, context or urgent needs. More successful foreign language learners are those who use various strategies appropriately, so, these strategies help to best perform the tasks which were confirmed by the study. Moreover, the training outcomes have shown that the students who successfully master a foreign language show more flexibility in choosing appropriate learning strategies.

The effectiveness of the applied instructional explicit Oxford's model in the process of learning a foreign language is also confirmed by several other researches. For instance, the positive impact of learning strategies on the process of teaching speaking and writing has been noted in the works of Chamot (2005), Cohen (2006), Lee (2003), Zare (2012). The effectiveness of strategies in EFL of listening, reading, and vocabulary is proved in studies of Naeimi and Foo (2015), Taghinezhad et al. (2015), Taghinezhad et al. (2016), Thomson and Mehring (2016), and others.

Thus, the results have shown that strategies help students to control their learning, form and develop language skills, strengthen confidence and motivation to learn a foreign language. As a result the implementation of proposed direct and indirect strategies has increased the level of English proficiency and helped students to take responsibility for their learning.

As the size of the sample is rather small, the survey results cannot be generalized as the sample $(n=58)$ selected cannot exemplify the entire population at large. Rather, this study should be considered as an exploratory investigation that has the goal of identifying possible issues and trends for further research. 


\section{CONCLUSIONS}

The study has revealed that strategies acquisition in autonomous learning of professionally oriented English communication could be very helpful in the development of English communicative proficiency and academic achievements.

Active use of foreign language learning strategies helps students to control their own learning, develop language and speech skills, increase confidence and motivation to learn a language. Applying learning strategies increases autonomy and promotes students take responsibility for their learning. The more strategies students use the more confident, motivated and independent they feel. The priority task of the teacher is the selection of appropriate teaching methods and strategies for students and the formation of their ability to use these strategies properly to increase the level of their autonomy in learning.

The results have indicated that the main task in instructing students to apply learning strategies is to provide them with the tools to perform the necessary actions: self-diagnosis, identification of strengths and weaknesses in the educational process; awareness of what helps to learn a foreign language more effectively; formation of skills and abilities that contribute to the successful solution of problems; experimentation, i.e. the implementation of already known and new learning strategies; decision-making on the use of educational techniques to solve the problem; the need for self-control and constant monitoring of the educational activities; transfer of "successful" learning strategies to the new educational content.

It has been found that the repertoire of existing student learning strategies expands and his / her individual learning style becomes more mobile when joining new ways of perception and processing of educational materials to the available resources of the student's personality, which characterize his individual learning style.

Thus, the implementation of learning strategies facilitates and improves the process of autonomous learning of professionally oriented English communication. Mastering learning strategies helps students to organize independent learning of a foreign language, thereby forming its trajectory of autonomous learning. The ability to take responsibility for one's educational activities and the ability to learn are key components of autonomous learning. The development of these skills will ensure intending educators' ability to self-development and self-improvement throughout a life.

\section{REFERENCES}

Anderson, N. (2005). L2 learning strategies. In E. Hinkel (Ed.), Handbook of research in second language teaching and learning. Lawrence Erlbaum Associates.

Bergman, J. B. (1991). Metacognitive Strategies in Advanced Placement English Language and Composition. University of South Florida, Advanced placement programs (Education).

Bialystok, E. (1981). The role of conscious strategies in second language proficiency. Modern Language Journal, 65 (1), 24-35. https://doi.org/10.1111/j.1540-4781.1981. tb00949.x

Bimmel P., Rampillon N. (1999). Lernerautonomie und Lernstrategien [Learning Autonomy and Learning Strategies]. Langenscheidt: Berlin-München-Leipzig.

Bruen, J. (2001). Strategies for success: Profiling the effective learners of German. Foreign Language Annals, 34(3), 216-225. https://doi.org/10.1111/j.1944-9720.2001. tb02403.x 
Chamot, A. U., \& Kupper, L. (1989). Learning strategies in foreign language instruction. Foreign Language Annuals, 22, 13-24. https://doi.org/10.1111/j.1944-9720.1989. tb03138.x

Chamot, A. U., \& O’Malley, J. M. (1987). The cognitive academic language learning approach: A bridge to the mainstream. TESOL Quarterly, 21, 227-249. https://doi.org/10.2307/3586733

Chamot, A. U. (2004). Issues in language learning strategy research and teaching. Electronic Journal of Foreign Language Teaching, 1(1), 14-26. https://doi.org/10. 4236/jss.2019.73014

Chamot, A. U. (2005). The Cognitive Academic Language Learning Approach (CALLA): An update. In P.A. Richard-Amato \& M.A. Snow (Eds.), Academic success for English language learners: Strategies for K-12 mainstream teachers (pp. 87-101). Longman.

Cohen, A. (1990). Language learning: Insights for learners, teachers, and researchers. Newbury House.

Cohen, A. (2006). Styles and Strategies-Based Instruction: A Teachers' Guide. Centre for Advanced Research on Language Acquisition, University of Minnesota.

Cohen, A. D. (1998, 2000). Strategies in Learning and Using a Second Language. Addison Wesley Longman Ltd.

Cotterall, S. (2008). Autonomy and Good Language Learners. In Griffiths, C. (ed.), Lessons from Good Language Learners, pp. 83-98. Cambridge University Press.

Council of Europe. (2018). Common European Framework of reference for languages: learning, teaching, assessment - Companion volume with new descriptors. Council of Europe Publishing.

Dmitrenko N., Petrova A., \& Podzygun O.. (2020). Problem-Based Tasks in Foreign Language Acquisition for Intending Educators. Society. Integration. Education. Proceedings of the International Scientific Conference. Volume V. Lifelong Learning. Innovation in Language Education. Art and Design. May 22th-23th, 2020. Rezekne, Rezekne Academy of Technologies, 361-373. http://doi.org/10.17770/sie2020vol5.4984

Dmitrenko, N., Dolia, I., \& Nikolaaeva, S. (2020). Soft Skills Development of Prospective Educators by Means of Problem-Based ESP Learning. The New Pedagogical Review, 6(2), 124-135. https://doi.org/10.15804/tner.2020.60.2.10

Dmitrenko, N., Nikolaeva, S., Melnyk, L., \& Voloshyna, O. (2020). Autonomous ESP Learning of Prospective Teachers of Mathematics. Revista Romaneasca pentru Educatie Multidimensionala, 12(1), 86-104. https://doi.org/10.18662/rrem/201

Ehrman, M. E. \& Oxford, R. L. (1989). Effects of sex differences, career choice, and psychological type on adult language learning strategies. The Modern Language Journal, 73, 1-3. https://doi.org/10.1111/j.1540-4781.1989.tb05302.x

Ellis, R. (1994). The study of second language acquisition. Oxford University Press.

Faerch, C., \& Kasper G. (1989). Internal and external modification in interlanguage request realization. S. Blum-Kulka, J. House, \& G. Kasper (Eds.). Crosscultural pragmatics. Ablex, 221-247.

Fujiware, B. (1990). Learner training in listening strategies. JALT Journal, 12(2), 203-217.

Green, J. M., \& Oxford, R. L. (1995). A closer look at learning strategies, L2 proficiency, and gender. TESOL Quarterly, 29(2), 261-297. https://doi.org/10.2307/3587625

Grenfell, M., \& Harris, V. (1999). Modern languages and learning strategies: In theory and practice. Routledge. 
Griffiths, C. (2003). Patterns of language learning strategy use. System, 31, 367-383. https://doi.org/10.1016\%2FS0346-251X(03)00048-4

Griffiths, C. (2013). The strategy factor in successful language learning. Multilingual Matters.

Lai, Ying-Chun. (2013). Integrating vocabulary learning strategy instruction into EFL classrooms. Taiwan Journal of TESOL, 10(1), 37-76.

Lee, K. (2003). The relationship of school year, sex and proficiency on the use of learning strategies in learning English. Asian EFL Journal, 5(4), 1-36.

Liu, J. (2010). Language learning strategies and its training model international. Education Studies, 3(3), 100-104. https://doi.org/10.5539/ies.v3n3p100

Macaro, E., \& Erler, L. (2008). Raising the achievement of young-beginner readers of French through strategy instruction. Applied Linguistics, 29, 90-119. https://doi.org/10.1093/ applin/amm023

Naeimi, M., \& Foo, T. (2015). Vocabulary acquisition through direct and indirect learning strategies. English Language Teaching, 8 (10), 142-151. https://doi.org/10. 5539\%2Felt.v8n10p142

Nakatani, Y. (2005). The effects of awareness-raising training on oral communication strategy use. The Modern Language Journal, 89(1), 76-92. https://doi.org/10.1111/ j.0026-7902.2005.00266.x

Nguyen, L. T. C., \& Gu, P. Y. (2013). Strategy-based instruction: A learner-focused approach to developing learner autonomy. Language Teaching Research, 17(1), 9-30. https://doi.org/10.1177\%2F1362168812457528

O'Malley, J. M., \& Chamot, A. U. (1990). Learning strategies in second language acquisition. Cambridge University Press.

O’Malley, J. M., Chamot, A. U., Stewner-Manzanares, G., Kupper, L. J., \& Russo, R. P. (1985). Learning strategies used by beginning and intermediate ESL students. Language Learning, 35(1), 21-46. https://doi.org/10.1111/j.1467-1770.1985.tb01013.x

O'Malley, M., \& Chamot, A. U. (1994). The CALLA handbook: implementing the cognitive academic language learning approach. Addison-Wesley, Reading MA. Longman.

Oxford, R. L. (1990). Language learning strategies: What every teacher should know. Newbury House / Harper \& Row.

Oxford, R. L. (2003). Language learning styles and strategies: An overview. Learning Styles \& Strategies. GALA, 1-25.

Oxford, R. L., \& Cohen, A. D. (1992). Language learning strategies: Crucial issues of concept and classification. Applied Language Learning, 3, 1-35.

Oxford, R. L., \& Ehrman, M. E. (1995). Adults' language learning strategies in an intensive foreign language program in the United States. System, 23, 359-386. https://doi.org/10.1016/0346-251X(95)00023-D

Oxford, R. L., \& Leaver, B. L. (1996). A synthesis of strategy instruction for language learners. In R. L. Oxford (Ed.), Language learning strategies around the world: Cross-cultural perspectives, 227-246. University of Hawaii Press.

Oxford, R. L., Nyikos, M., \& Ehrman, M. (1988). Vive la difference? Reflections on sex differences in use of language learning strategies. Foreign Language Annuals, 21, 321-329. https://doi.org/10.1111/j.1944-9720.1988.tb01076.x

Ozeki, N. (2000). Listening strategy instruction for female EFL college students in Japan. Unpublished doctoral dissertation, Indiana University of Pennsylvania. 
Person, P. D., \& Dole, J. A. (1987). Explicit comprehension instruction: a review of research and a new conceptualization of learning. Elementary School Journal, 88(2), 151-165. https://doi.org/10.1086/461530

Rahimi, M., Riazi, A., \& Saif, S. (2008). An investigation into the factors affecting the use of language learning strategies by Persian EFL learners. CJAL, 11(2), 31-60.

Richards, J. C., Platt, J., \& Platt H. (1992). Longman dictionary of language teaching and applied linguistics. Longman.

Rubin, J. (1975). What the "good language learner" can teach us. TESOL Quarterly, 9(1), 41-51.

Rubin, J. (1981). Study of cognitive processes in second language learning. Applied Linguistics, 2, 117-131. https://doi.org/10.1093/applin/II.2.117

Sarada, Jarupan. (2019). The use of '5a learning portfolio', a technique of learning strategies based on self-directed learning and metacognition to enhance english learning skills of thai engineering students. PSAKU International Journal of Interdisciplinary Research, 8(1), 35-47.

Schultz, J. M. (1991). Mapping and cognitive development in the teaching of foreign language writing. The French Review, 64 (6), 978-88.

Shi, H. (2017). Learning strategies and classification in education. Institute for Learning Styles, 1(Fall), 24-36.

Stern, H. H. (1992). Issues and options in language teaching. OUP.

Taghinezhad, A., Azizi, M., Shahmohammadi, S., Kashanifar, F., \& Azadikhah, M. (2016). Comparing the effects of direct and indirect learning strategies on Iranian EFL learners' vocabulary learning. Journal of Applied Linguistics and Language Research, 3, 133-143.

Taghinezhad, A., Dehbozorgi, R., \& Esmaili, N. (2015). The influence of teaching metacognitive reading strategies on the reading self-efficacy beliefs of Iranian EFL learners: An experimental study. Modern Journal of Language Teaching Methods, 4 (5), 728-734.

Taghinezhad, A., Tabaeifard, J., \& Bazyar, Z. (2015). Investigating the impact of teaching listening comprehension strategies on the improvement of listening comprehension ability of Iranian EFL learners. International Journal of English Language, Literature, and Translation Studies, 2(3), 397-403.

Thompson, I. \& Rubin, J. (1996). Can strategy instruction improve listening comprehension? Foreign Language Annals, 29(3), 331-42. https://doi.org/10.1111\% 2Fj.1944-9720.1996.tb01246.x

Thomson, R., \& Mehring, J. (2016). Better vocabulary study strategies for long term learning. Kwansei Gakuin University Humanities Review, 20, 133-141.

Urlaub, P. (2012). Reading strategies and literature instruction: Teaching learners to generate questions to foster literary reading in the second language. System, 40, 296304. http://doi.org/10.1016/j.system.2012.05.002

Weinstein, C. E., \& Mayer, R. E. (1986). The teaching of learning strategies. In M. C. Wittrock (Ed.), Handbook of research on teaching (3rd ed. pp. 315-327). Macmillan.

Wenden, A. L. (1986). Helping language learners think about learning. ELT Journal, 40(1), 3-12.

Wenden, A., \& J. Rubin. (1987). Learner strategies in language learning. Englewood Cliffs, Prentice Hall. 
Williams, M., \& Burden R. L. (1997). Psychology for language teachers: A Social Constructive Approach. CUP.

Willing, K. (1988). Learning Styles in Adult Migrant Education. NCRC.

Zare, P. (2010). An investigation into language learning strategy use and gender among iranian undergraduate language learners. World Applied Sciences Journal, 11(10), $1238-1247$.

Zare, P. (2012). Language learning strategies among EFL/ESL learners: A review of literature. International Journal of Humanities and Social Science, 2(5), 162-169. 